\section{REFERENCES}

1. Gaull G, Sturman JA, Räiha NCR 1972 Development of mammalian sulfur metabolism. Absence of cystathionase in human fetal tissues. Pediatr Res 6:538-547

2. Snyderman SE 1971 The protein requirements of the premature infant. In: Jonxis JHP, Visser HKA Troelstra JA (eds) Nutrica Symposium, Metabolic Processes in the Foetus and Newborn Infant. Stenfert Kruesse, Leiden, pp $128-143$

3. Sturman JA, Gaull G, Räiha NCR 1970 Absence of cystathionase in human fetal liver. Is cystine essential? Science 169: 74-75

4. Pohlandt F 1974 Cystine: a semi-essential amino acid in the newborn infant. Acta Paediatr Scand 63:801-804

5. Stegink LD 1975 Amino acid metabolism. In: Winters RW, Hasselmeyer EG (eds) Intravenous Nutrition in the High Risk Infant. John Wiley \& Sons, New York, pp 181-203

6. Stegink LD, Baker GL 1971 Infusion of protein hydrolysates in the newborn infant: Plasma amino acid concentrations. J Pediatr 78: 595-603

7. Stegink LD 1977 Peptides in parenteral nutrition. In: Green HL, Holliday MA, Munro HN (eds) Clinical Nutrition Update: Amino Acids. American Medical Association, Chicago, pp 192-198

8. Daabees TT, Stegink LD 1978 L-Alanyl-L-tyrosine as a tyrosine source during intravenous nutrition of the rat. J Nutr 108:1104-1113

9. Daabees TT, Stegink LD 1979 L-Alanyl-L-tyrosine as a tyrosine source during total parenteral nutrition. Infusion at 0.5 and $2 \mathrm{mmoles} / \mathrm{kg} /$ day in adult rats. Pediatr Res 13:894-899

10. Sheehan JC, Yang D-DH 1958 The use of $\mathrm{N}$-formylamino acids in peptide synthesis. J Am Chem Soc 80:1154-1158

11. Palese M, Tephly TR 1975 Metabolism of formate in the rat. J Toxicol Environ Health $1: 13-24$

12. Popovic V, Popovic P 1960 Permanent cannulation of aorta and vena cava in rats and ground squirrels. J Appl Physiol 15:727-728

13. Steiger E, Vars HM, Dudrick SJ 1972 A technique for longterm intravenous feeding in unrestrained rats. Arch Surg 104:330-332

14. Warner RG 1952 Nutrient requirements of the laboratory rat. In: Nutrien
Requirements of Domestic Animals. Laboratory Animals. Publication 990. National Academy of Sciences-National Research Council, Washington, D.C. pp $56-93$

15. Efron ML 1966 Quantitative estimation of amino acids in physiological fluids using a Technicon amino acid analyzer. In: Skeggs LT (ed) Automation In Analytical Chemistry. Mediad Inc., New York, pp 637-642

16. Stegink LD 1970 Simultaneous measurement of radioactivity and amino acid composition in physiological fluids during amino acid toxicity studies. In: Advances in Automated Analysis, Vol 1. Halos Associates, Miami, pp 591594

17. Bray GA 1960 A simple efficient liquid scintillator for counting aqueous solutions in a liquid scintillation counter. Anal Biochem 1:279-285

18. Steel RG, Torrie JW 1960 Probability. In: Principles and Procedures of Statistics. McGraw Hill, New York, pp 49-66

19. Birnbaum SM, Levintow L, Kingsley RB, Greenstein JP 1952 Specificity of amino acid acylases. J Biol Chem 194:455-470

20. Bruns FH, Schulze C 1962 Acylase I. Reintarstellung, physiakalisch-chemische. Eigenschaften und identitiat mit hippurikase. Biochem Z 336:162-181

21. Greenstein JP, Winitz M 1961 Enzymes involved in the determination, char acterization and preparation of the amino acids. In: Chemistry of the Amino Acids, Vol 2. John Wiley \& Sons, New York, pp 1753-1861

22. Lorentz K, Voss J, Flatter B 1975 A new method for the assay of aminoacylase: elaboration of a fixed-incubation method for routine measurements. Clin Chim Acta 63:263-269

23. D'Adamo AF, Smith JC, Woiler C 1973 The occurrence of N-acetylaspartate amidohydrolase (Aminoacylase II) in the developing rat. $\mathbf{J}$ Neurochem 20:1275-1278

24. Goldstein FB 1976 Amidohydrolases of brain: enzymatic hydrolysis of $\mathrm{N}$-actylL-aspartate and other N-acyl-L-amino acids. J Neurochem 26:45-49

25. Endo $Y 1978 \mathrm{~N}$-Acyl-L-aromatic amino acid deacylase in animal tissues Biochim Biophys Acta 523:207-214

26. Snyderman SE 1975 Recommendations for parenteral amino acid requirements. General discussion. In: Winters RW, Hasselmeyer EG (eds) Intravenous Nutrition In the High Risk Infant. J. Wiley \& Sons, New York, pp $422-425$

\title{
A Follow-Up Study of the Effects of Early Malnutrition on Subsequent Development. I. Physical Growth and Sexual Maturation during Adolescence
}

\author{
JANINA R. GALLER, FRANK RAMSEY, AND GIORGIO SOLIMANO
}

Department of Child Psychiatry [J.R.G.], Boston University School of Medicine, Boston, Massachusetts 02118, the Institute of Human Nutrition and Center for Population and Family Health [G.S.]. Columbia University, New York, New York 10032; and National Nutrition Centre [F.R.], Bridgetown, Barbados, West Indies

\begin{abstract}
A follow-up study of growth and development was conducted on 216 Barbadian children aged 9 to $15 \mathrm{yr}$, half of whom had histories of moderate to severe protein-energy malnutrition in their 1st yr of life. Although index girls had significant delays in sexual maturation and were reduced relative to comparison girls on measures of weight for height, arm circumference, and skinfold thick-
\end{abstract}

Received July 9, 1984; accepted January 24, 1985.

Reprint requests Dr. Janina R. Galler, Department of Child Psychiatry, Boston University School of Medicine, 85 East Newton Street, Suite M921, Boston, MA 02118.

This work was performed in collaboration with the Ministries of Health and Education of Barbados and was supported by grants from the Thrasher Research Fund and the Ford Foundation. ness, their rate of growth when compared with values obtained 4 yr earlier was equal to or better than that of the comparison group. In contrast, boys in the index group were slightly reduced in height compared with their matched comparisons and had similar patterns of growth and sexual maturation. This study suggests a relationship between an episode of infantile malnutrition and impaired endocrine functioning among girls in the adolescent years. (Pediatr Res 19: 518-523, 1985)

\section{Abbreviations}

MANOVA, 2-way multivariate analysis of variance ANOVA, 2-way univariate analysis of variance 
This paper is one of a series of reports describing the longterm consequences of protein-energy malnutrition in the $1 \mathrm{st} \mathrm{yr}$ of life $(1-7)$. We have previously reported significant deficits in the physical growth of children aged 5 to 11 yr who had histories of malnutrition, especially in the girls of this population (3). Although the index children came from homes which were slightly more disadvantaged than those of comparison children without histories of malnutrition, these socioeconomic conditions measured concurrently did not contribute significantly to the differences in growth between index and comparison children (7). We believe this to be a reflection of the relatively homogeneous Barbadian population and also the possible compensatory role of enrollment in the National Nutrition Centre which followed our index population until $11 \mathrm{yr}$ of age.

Herein we describe the growth of these same children at followup 4 yr later, when they were 9 to $15 \mathrm{yr}$ of age, including measures of sexual maturation assessed by the Tanner scale $(8$, 9 ). We show that the onset of pubescence is delayed in index girls and this finding is associated with a reduction in mean heights and weights, whereas index boys are no longer small as compared to comparison boys. However, the velocity of growth over this period is highest among index girls.

\section{METHODS}

This study was conducted at the National Nutrition Centre in Barbados (10). Since 1967, this center has provided medical care to children with malnutrition from the time of diagnosis to 11 yr of age. All cases of malnutrition in Barbados must be reported to the National Nutrition Centre, and, thus, good documentation is available on a population of approximately 2100 children. Several features of the Barbadian population were favorable to our investigation. First, the delivery and documentation of health care are good. Almost all children are born in the Queen Elizabeth Hospital or allied facilities, and records of obstetric and perinatal care are available in almost all cases. Furthermore, children are followed routinely by local clinics and these records were made available to us. Second, education is almost universal. Nearly all children attend school to $16 \mathrm{yr}$ of age, and $95 \%$ of the Barbadian population is literate. Comprehensive school records are available for each child. Third, the population is stablewith little in or out migration-and is largely homogeneous with respect to ethnicity and socioeconomic level, which is mostly lower middle class. Because of all these advantages we were able to obtain extensive documentation of index and comparison children during infancy (including specific details surrounding the episode of malnutrition for index children), early childhood, and at the time of the study.

Study population. In the earlier series of studies, 129 index children of ages 5 to 11 were selected using the following criteria:

1) They had been diagnosed on clinical examination by one of our group (F.R.) as showing the symptoms of protein-energy malnutrition, including moderate to severe weight loss (below $75 \%$ of expected weight for age) in the absence of edema, during the 1 st yr of life. Further episodes of malnutrition are rare in this population, and only children with a single episode were included.

2) Their birth weight was at least $5 \mathrm{lb}$ to exclude those children exposed to significant fetal growth retardation.

3) They had no evidence of prenatal or perinatal complications, as measured by standard criteria including the Apgar score.

4) They had no history of convulsion, head injury, or loss of consciousness.

The index children were hospitalized at the Queen Elizabeth Hospital for a period of $37 \pm 15$ days and were then followed by the National Nutrition Centre through 11 yr of age, where they received medical care, including home visits, nutritional counseling, and subsidized milk.

The comparison children were for the most part classmates of the index children and were matched to them by sex and age.
Except for the fact that they did not have histories of malnutrition and had documented normal growth during childhood, the cornparison children met the same criteria as the index children.

In the present investigation, we have followed the same child population $4 \mathrm{yr}$ later in order to determine changes associated with growth and development into adolescence. We were successful in identifying 109 (or $85 \%$ of the original sample) of index children and 107 of the comparison group.

Data collected. Anthropometric measures (11) were obtained at the National Nutrition Centre by two pediatricians who were blind to the nutritional history of the children. Height was measured to the nearest $1 / 2 \mathrm{~cm}$ with the subject standing (without shoes) and sitting. Children were weighed in the underclothes using an adult Detecto (Long Island City, NY) office scale, which was calibrated prior to each reading. Arm circumference was measured on the left arm at a level halfway between shoulder and elbow. An "insertion tape" was used which has a window through which the end of the tape was pulled. Skinfold thickness was measured using Lange calipers.

Measures of sexual maturation using the Tanner scale $(8,9)$ were also made by the pediatrician as part of a general medical evaluation. Breast and pubic hair development were assessed in girls and genitalia (penile size and testicular growth) and pubic hair in boys. In each case, maturation was recorded using a 5point scale, ranging from 1 -minimal or no pubescent changes to 5-complete sexual maturation. The number of index and comparison girls in this population who had achieved menarche and the age of menarche were recorded. Physical examination was normal for all children in the study for indices other than growth and sexual maturation, and consequently there were no significant differences between index or comparison groups.

Statistical analyses. All analyses were performed using the Statistical Package for the Social Sciences (12) and data for boys and girls were analyzed separately. In order to determine whether differences in physical growth and development were attributable to early nutritional history, we performed a MANOVA with age (seven levels) and nutritional history (two levels) as independent variables and all the anthropometric measures as dependent variables. This was followed by an ANOVA for each individual anthropometric measure.

Sexual maturation as assessed by the Tanner scale was similarly analyzed using the MANOVA (nutritional history by age) with all the growth measures as the dependent variables. This was followed by ANOVA for individual measures of sexual maturation. The percentage of index and comparison girls who had achieved menarche at the time of this study were compared using $\chi^{2}$ analysis and the mean age of onset was compared using a Student's $t$ test. Finally, in order to examine the possible role of height and weight in sexual maturation, including age at menarche, the data were analyzed by MANOVA with height and weight entered as covariates.

\section{RESULTS}

Anthropometric measures. Mean values of physical growth of index (46 girls and 62 boys) and comparison children are presented in Table 1. For almost every measure, index girls and especially those in the older age group had lower values than did their comparisons, whereas values for index boys were similar to or only slightly lower than those of the comparison boys in all age groups. In order to analyze the overall relationships of nutritional history to physical growth, we applied a 2-way MANOVA with nutritional history (two levels) and age (seven levels) as independent variables and all 10 growth measures as dependent variables. In the case of the girls, the MANOVA confirmed highly sufficient differences between index and comparison children $[\mathrm{F}(10,650)=3.92 ; p<0.001]$ and significant age effects [F $(60,429)=2.06 ; p<0.001]$. Similar findings were obtained for the boys, although differences between index and comparison groups were less striking. There was no interaction between age 
Table 1. Mean values $( \pm S D)$ of anthropometric measures for children with histories of early malnutrition and the comparison groups at 9 to 15 yr of age

\begin{tabular}{|c|c|c|c|c|}
\hline \multirow[b]{2}{*}{ Measures } & \multicolumn{2}{|c|}{ Male } & \multicolumn{2}{|c|}{ Female } \\
\hline & $\begin{array}{c}\text { Comparison } \\
(n=64)\end{array}$ & $\begin{array}{l}\text { Index } \\
(n=62)\end{array}$ & $\begin{array}{l}\text { Comparison } \\
(n=43)\end{array}$ & $\begin{array}{l}\text { Index } \\
(n=46)\end{array}$ \\
\hline $\mathrm{Ht}(\mathrm{cm})$ & $150.40 \pm 12.18$ & $148.92 \pm 12.50$ & $149.63 \pm 11.02$ & $145.25 \pm 11.40$ \\
\hline Upper segment length $(\mathrm{cm})$ & $69.01 \pm 4.67$ & $68.61 \pm 5.20$ & $69.37 \pm 4.59$ & $66.21 \pm 5.30$ \\
\hline Lower segment length $(\mathrm{cm})$ & $81.32 \pm 7.89$ & $78.80 \pm 8.26$ & $80.38 \pm 6.95$ & $78.78 \pm 6.62$ \\
\hline Upper/lower segment ratio & $0.86 \pm 0.04$ & $0.88 \pm 0.06$ & $0.86 \pm 0.05$ & $0.84 \pm 0.05$ \\
\hline $\mathrm{Wt}(\mathrm{kg})$ & $39.37 \pm 10.35$ & $37.02 \pm 10.74$ & $41.90 \pm 11.47$ & $35.42 \pm 7.63$ \\
\hline $\mathrm{Wt} / \mathrm{ht}$ & $0.26 \pm 0.05$ & $0.25 \pm 0.05$ & $0.28 \pm 0.06$ & $0.24 \pm 0.04$ \\
\hline Arm circumference $(\mathrm{cm})$ & $21.01 \pm 2.51$ & $20.72 \pm 2.73$ & $21.77 \pm 3.08$ & $20.38 \pm 1.79$ \\
\hline $\begin{array}{l}\text { Triceps skinfold thickness } \\
(\mathrm{mm})\end{array}$ & $7.00 \pm 2.71$ & $7.70 \pm 3.98$ & $12.39 \pm 4.86$ & $10.43 \pm 2.78$ \\
\hline $\begin{array}{l}\text { Subscapular skinfold thick- } \\
\text { ness }(\mathrm{mm})\end{array}$ & $5.86 \pm 1.44$ & $6.20 \pm 2.99$ & $9.66 \pm 4.35$ & $7.73 \pm 2.54$ \\
\hline $\begin{array}{l}\text { Suprailiac skinfold thickness } \\
(\mathrm{mm})\end{array}$ & $6.00 \pm 2.47$ & $6.17 \pm 3.74$ & $9.95 \pm 5.33$ & $7.83 \pm 3.18$ \\
\hline
\end{tabular}

Table 2. F values derived from analysis of variance (nutritional history $\times$ age) of anthropometric measures performed separately for boys and girls

\begin{tabular}{|c|c|c|c|c|c|c|}
\hline \multirow[b]{3}{*}{ Dependent variables } & \multicolumn{6}{|c|}{ Independent variables } \\
\hline & \multicolumn{2}{|c|}{ Nutritional history } & \multicolumn{2}{|c|}{ Age } & \multicolumn{2}{|c|}{ Nutritional history $\times$ age } \\
\hline & $\begin{array}{c}\text { Male } \\
(\mathrm{df}=1,100)\end{array}$ & $\begin{array}{c}\text { Female } \\
(\mathrm{df}=1,74)\end{array}$ & $\begin{array}{c}\text { Male } \\
(\mathrm{df}=16,110)\end{array}$ & $\begin{array}{c}\text { Female } \\
(\mathrm{df}=6,74)\end{array}$ & $\begin{array}{c}\text { Male } \\
(\mathrm{df}=6,110)\end{array}$ & $\begin{array}{c}\text { Female } \\
(\mathrm{df}=6,74)\end{array}$ \\
\hline $\mathrm{Ht}$ & $4.90^{*}$ & $15.30 \dagger$ & $41.34 \dagger$ & $27.86+$ & 0.62 & 0.61 \\
\hline Wt & 3.10 & $28.88 \dagger$ & 26.37 & $21.98 \dagger$ & 0.44 & 0.84 \\
\hline Wt/ht & 2.12 & $28.68 \dagger$ & $19.40 \dagger$ & $15.91 \dagger$ & 0.60 & 1.01 \\
\hline Arm circumference & 0.63 & $11.02 \div$ & $14.88 \dagger$ & $6.83 \dagger$ & 0.61 & 0.79 \\
\hline Upper segment length & 0.52 & $29.52 \dagger$ & $26.31+$ & $23.10 \dagger$ & 1.33 & 0.63 \\
\hline Lower segment length & $7.94 \ddagger$ & $4.32^{*}$ & $38.34 \dagger$ & $19.18 \dagger$ & 0.44 & 0.98 \\
\hline Upper/lower segment ratio & $5.74^{*}$ & $5.29 *$ & $7.96 \dagger$ & 1.54 & 1.27 & 1.45 \\
\hline Triceps skinfold thickness & 0.20 & $4.96^{*}$ & 0.90 & 1.45 & 0.57 & 1.11 \\
\hline Subscapular skinfold thickness & 0.76 & $8.24 \ddagger$ & $2.22 *$ & $4.11 \neq$ & 0.93 & 1.62 \\
\hline Suprailiac skinfold thickness & 0.10 & $5.75^{*}$ & 1.67 & $3.79:$ & 1.57 & 0.55 \\
\hline
\end{tabular}

$$
\begin{aligned}
& * p<0.05 . \\
& \dagger p<0.001 . \\
& \ddagger p<0.01
\end{aligned}
$$

and the nutritional history of the child. In summary both index boys and girls had reduced physical growth relative to comparison children of the same sex and age, although this effect was greater among the girls.

The results of analyses of the individual measures of growth are summarized in Tables 1 and 2 and are described below. It should be noted that height and weight are the most sensitive indicators of previous infantile malnutrition.

Height. Figures $1 A$ and $B$ show the mean heights at each age plotted against the 10th, 50th, and 90th percentiles of the 1977 National Center for Health Statistics curves for children (13) and Table 1 summarizes these mean values. For both boys and girls, the comparison children fell at or near the 50th percentile. Whereas index boys were reduced at younger ages, they did not differ from comparison boys at $15 \mathrm{yr}$ of age. However, index girls were shorter than comparison girls at all ages. These data were analyzed using univariate analysis of variance (nutritional history by age) separately for boys and girls (Table 2). As may be seen, both index boys and girls were significantly shorter, but this effect was more significant for index girls.

In contrast, when we examined rate of growth by comparing heights at the time of this study with heights achieved 4 yr earlier, we found a higher rate of growth for index girls than for any other group. Index girls grew approximately 25 versus $22 \mathrm{~cm}$ for comparison girls, whereas index boys had the same growth increment as their matched comparisons (about $23 \mathrm{~cm}$ ). ANOVA showed differences in rate growth to be significantly higher for index girls $[\mathrm{F}(1,690)=5.4 ; p<0.05]$, whereas index and comparison boys did not differ. Age effects were present for both boys and girls, because of rapid growth at this age period, but there was no interaction between nutritional history and age.

Body segment length. These data are summarized in Tables 1 and 2. Although both boys and girls with histories of malnutrition were shorter than their age-matched comparisons, the relative reduction in length of upper (sitting height) and lower body segments (leg length) differed between the sexes. Thus, index girls had a significant reduction in upper body length, and index boys had a significant reduction in lower segment length. Age effects were present for both of these measures of length, but there was no interaction of age and nutritional history for these measures.

Weight. Figures $2 A$ and $B$ present the weights of children in the study plotted against the standard percentiles of the 1977 National Center for Health Statistics growth curves. As may be seen, comparison girls fell at about the 50th percentile of the US standard, whereas the weights of index girls, which were similar to those of the comparison group at $9 \mathrm{yr}$ of age, declined over time, and by 13 yr of age and beyond, there were very large differences between index and comparison girls. In contrast, index and comparison boys differed only very little at all ages. It 

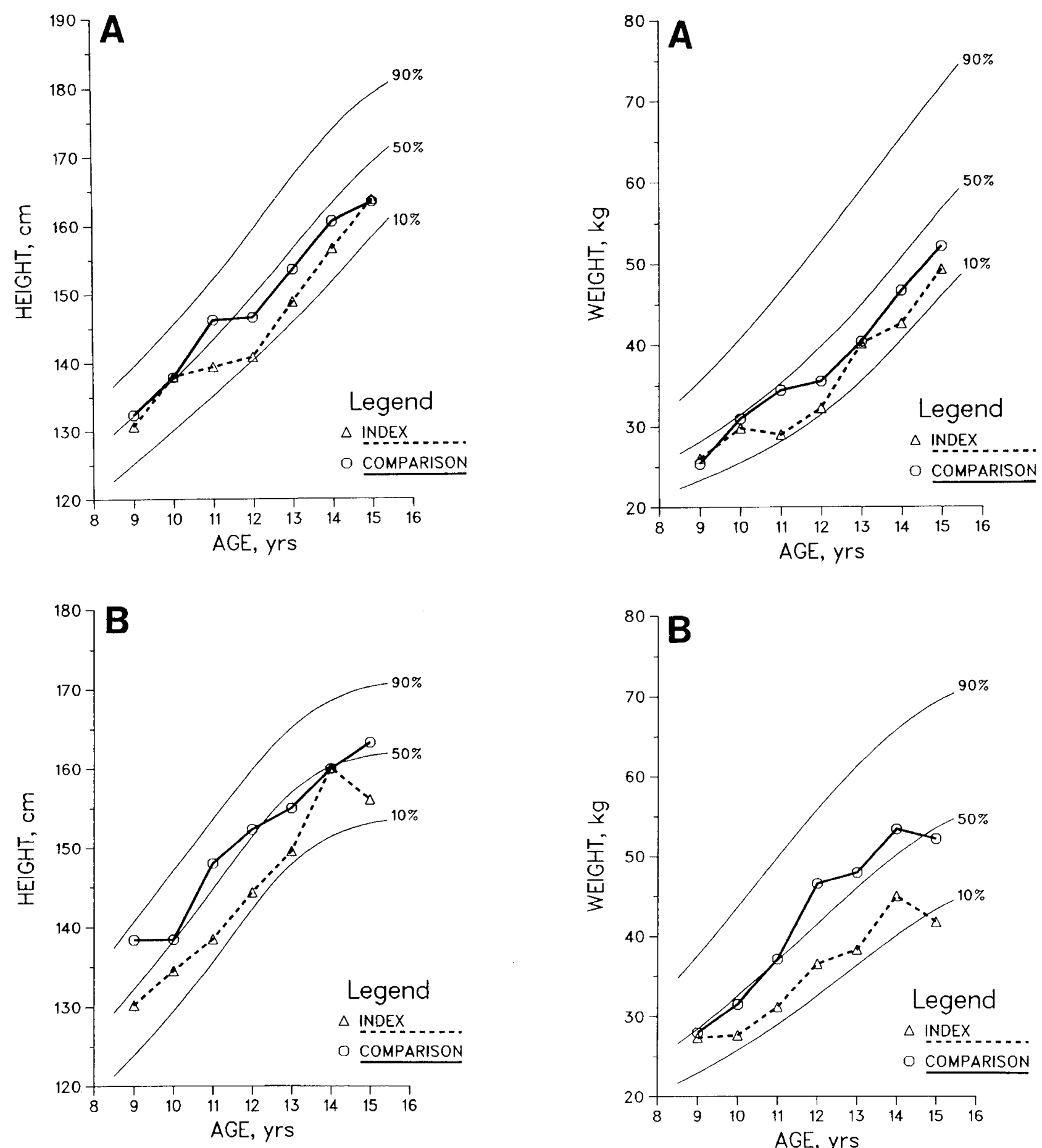

Fig. 1. Height for age in males $(A)$ and females $(B)$.

should be noted, however, that comparison boys had weights only at about the 25 th percentile of the US standard, and thus, the relative reduction among boys was less. These observations were confirmed by analysis of variance, which showed significant differences in weight between girls with and without histories of malnutrition, but not between boys from the two groups (Table 1). Age effects were also significant, and there was no interaction between nutritional history and sex. These findings persisted even when mean weights were corrected for height (Tables 1 and 2) with values for index girls only being significantly reduced.

Arm circumference. These findings were similar to those reported for weight (Tables 1 and 2). Thus, significant effects of nutritional history were found for girls but not for boys, since

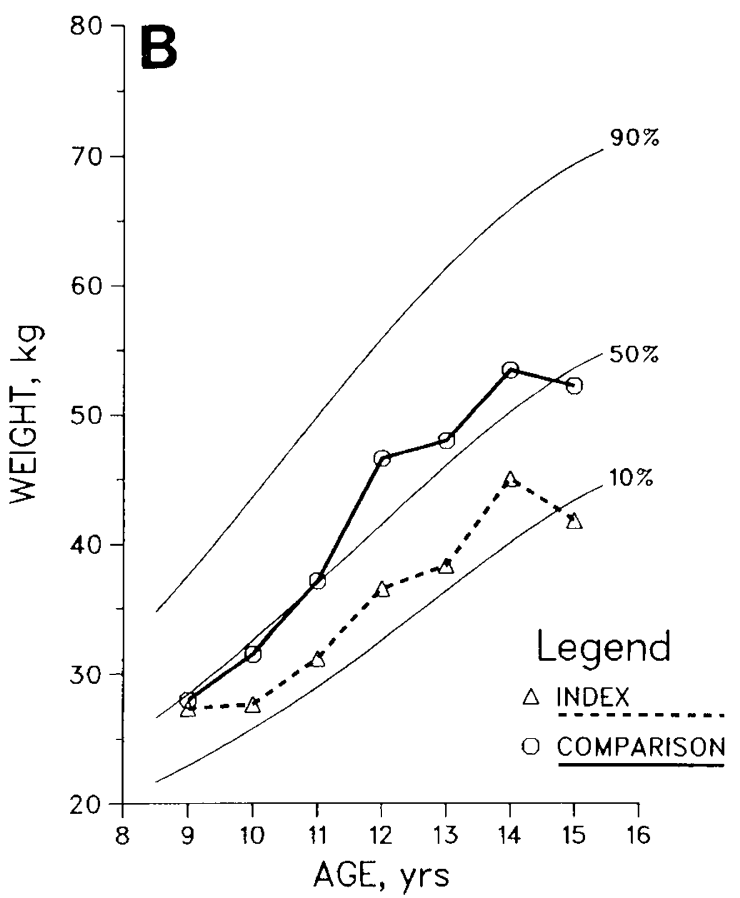

Fig. 2. Weight for age in males $(A)$ and females $(B)$.

comparison girls had much higher values than any of the three other groups.

Skinfold thickness: (triceps, subscapular, and suprailiac). As may be seen in Table 1, in each instance values for skinfold thickness were higher for girls than for boys. The relative reduction in skinfold thickness was greatest among index girls, in contrast to similar values for index and comparison boys. Analysis of variance confirmed significant reductions for index girls over all ages, but there was no such reduction among the boys (Table 2). Thus, skinfold thickness appears to be an especially sensitive measure of nutritional history for girls. This finding is probably a result of delayed sexual maturation in the index girls which is described in the next section. 
Sexual Maturation. Menarche. We found that the onset of menarche was delayed in girls with histories of malnutrition. Thus, at $11 \mathrm{yr}$ of age, $20 \%$ of the comparison group had achieved menarche as contrasted with none of the index girls, and at 12 yr these percentages were 75 and $0 \%$, respectively, for comparison and index girls. At $15 \mathrm{yr}$ of age, all comparison girls had achieved menarche, but $40 \%$ of the index girls were still premenarchal. In total, $44 \%$ of the 43 comparison girls aged 9 to $15 \mathrm{yr}$ had achieved menarche as contrasted with only $22 \%$ of the 45 index girls $\left(\chi^{2}=3.86 ; p<0.05\right)$. Among the girls who had achieved menarche, the mean age of onset for the comparison group was $11.7 \pm 1.1 \mathrm{yr}$ of age, and for the index group, $12.9 \pm$ $0.7 \mathrm{yr}$. This delay of slightly more than $1 \mathrm{yr}$ was significant by a Student's $t$ test $[\mathrm{t}(\mathrm{df}=27)=3.23 ; p<0.01]$.

Tanner scale. Breast and pubic hair development were assessed in girls and genitalia and pubic hair were assessed in boys. A MANOVA with all measures of sexual maturation as the dependent variables confirmed significant effects of prior nutritional history for girls $[\mathrm{F}(2,73)=5.69 ; p<0.01]$, but not for boys of this series since index girls were delayed relative to controls. Age effects were significant for both boys $[\mathrm{F}(18,336)=7.77 ; p<$ $0.001]$ and girls $[\mathrm{F}(12,148)=9.93 ; p<0.001]$. These analyses were supplemented by univariate ANOVA for each measure which are summarized in Table 3 . Briefly, ratings on the Tanner scale for both breast and pubic hair development were significantly lower at all ages in index girls. The data for pubic hair development are presented in Table 4 and are similar to those observed for breast development. As may be seen, index girls are delayed, until $13 \mathrm{yr}$ of age but thereafter they appear to catch up.

The analyses of age of menarche and sexual maturation were repeated controlling for weight and height, since reductions in these may have contributed to the observed findings. ANOVA with height and weight as covariates showed that delays in sexual development of girls in this population were largely accounted for by the reduction in height and weight in the sample since the effects of nutritional history were eliminated in this further analysis. Thus, sexual maturation was delayed in girls with histories of malnutrition, and this finding was associated with reduced height and weight.

\section{DISCUSSION}

The current study examined physical growth and sexual maturation in a population of Barbadian children, aged 9 to $15 \mathrm{yr}$, who were hospitalized with a moderate to severe episode of malnutrition in the $1 \mathrm{st} \mathrm{yr}$ of life and a matched comparison group. In earlier studies conducted when the children were 5 to

Table 3. $F$ values derived from analysis of variance (nutritional history $\times$ age) of Tanner scale ratings of sexual maturation, performed separately for boys and girls*

\begin{tabular}{|c|c|c|c|}
\hline \multirow[b]{2}{*}{ Dependent variables } & \multicolumn{2}{|c|}{ Independent variables } & \multirow{2}{*}{$\begin{array}{c}\text { Nutritional } \\
\text { history } \times \\
\text { age }\end{array}$} \\
\hline & $\begin{array}{c}\text { Nutritional } \\
\text { history }\end{array}$ & Age & \\
\hline Male & $(\mathrm{df}=1,112)$ & $(\mathrm{df}=6,112)$ & $(\mathrm{df}=6,112)$ \\
\hline Public hair & 3.58 & $37.65 t$ & 1.27 \\
\hline Penile development & 1.50 & $38.20 \dagger$ & 0.65 \\
\hline Testicular development & 3.15 & $46.94 \dagger$ & 0.76 \\
\hline Female & $(\mathrm{df}=1,74)$ & $(\mathrm{df}=6,74)$ & $(\mathrm{df}=6,74)$ \\
\hline Breast & $4.5 \ddagger$ & $31.47 \dagger$ & 0.96 \\
\hline Pubic hair & $11.25 \S$ & $26.39 \dagger$ & 0.74 \\
\hline
\end{tabular}

* The significant effect of nutritional history in females is not present when this analysis was repeated using height and weight as covariates.

$\dagger p<0.001$.

$\ddagger p<0.05$.

$\S p<0.01$.
Table 4. Percentage of girls achieving scores of 1 (prepubertal) to 5 (adult development) on the Tanner scale for pubic hair growth

\begin{tabular}{crrrcccc}
\hline \multirow{2}{*}{$\begin{array}{c}\text { Age } \\
\text { (yr) }\end{array}$} & & \multicolumn{5}{c}{ Scores on Tanner scale } \\
\cline { 3 - 8 } & & $n$ & 1 & 2 & 3 & 4 & 5 \\
\hline 9 & Comparison & 2 & 50.0 & 50.0 & 0 & 0 & 0 \\
& Index & 3 & 66.7 & 33.3 & 0 & 0 & 0 \\
10 & Comparison & 13 & 46.2 & 46.2 & 0 & 7.7 & 7 \\
& Index & 8 & 75.0 & 25.0 & 0 & 0 & 0 \\
11 & Comparison & 5 & 20.0 & 40.0 & 20.0 & 20.0 & 0 \\
& Index & 8 & 62.5 & 37.5 & 0 & 0 & 0 \\
12 & Comparison & 4 & 25.0 & 0 & 25.0 & 25.0 & 25.0 \\
& Index & 3 & 0 & 66.7 & 33.3 & 0 & 0 \\
13 & Comparison & 9 & 0 & 0 & 44.4 & 44.4 & 11.1 \\
& Index & 12 & 8.3 & 41.7 & 25.0 & 16.7 & 8.3 \\
14 & Comparison & 7 & 0 & 0 & 0 & 71.4 & 28.6 \\
& Index & 6 & 0 & 0 & 16.7 & 66.7 & 16.7 \\
15 & Comparison & 3 & 0 & 0 & 0 & 33.3 & 66.7 \\
& Index & 5 & 0 & 0 & 0 & 40.0 & 60.0 \\
\hline
\end{tabular}

$11 \mathrm{yr}$ of age, we reported that height and arm circumference were reduced in girls and especially in older girls in this population, but not in boys (3). Weight for height was not reduced in either boys or girls in the previous study. These deficits were not significantly associated with growth patterns of the mothers, who had similar heights and weights regardless of their child's nutritional history or differences in socioeconomic conditions.

We have now extended these observations to $15 \mathrm{yr}$ of age and have found that the growth deficits observed 4 yr earlier are still evident, especially in girls. However, the yearly increment in height (velocity) is the same for both comparison and index groups in the case of boys and significantly higher for index girls than comparison girls. This implies that the current status of the index group is not adversely influencing the rate of increase in height. Thus, the velocity of growth during adolescence does not show evidence of retardation due to the early history.

These data conform with those of Dreizen et al. (14) in their study of 30 Appalachian girls who were chronically undernourished during childhood. These authors observed delayed physical development including reduced height in the index girls which later caught up due to an increased adolescent growth velocity; however, other studies of the long-term effects of previous infantile malnutrition in Uganda (15) and South Africa (16) show persistent deficits in height among index children up to $18 \mathrm{yr}$ of age, but these studies are limited to single observations of final height. This does not allow determination of differences in velocity between malnourished and well-nourished groups. Thus, the adolescent catch-up by girls with histories of infantile malnutrition remains controversial.

In contrast, mean weights and weights/heights differentiated the index and comparison girls, especially from 13 to $15 \mathrm{yr}$ of age (Fig. $2 B$ ). This reduction is also reflected in arm circumference and skinfold thickness in the two groups of girls. These findings can be linked to the delay in sexual development among girls, but not boys with histories of malnutrition. Thus, the mean age of menarche was delayed by $1.2 \mathrm{yr}$, and there was a corresponding delay in breast and pubic hair development. The relationship between weight gain and menarche has been investigated by Frisch and Revelle (17) who propose the necessity of reaching a critical weight to achieve the onset of menstruation, although this concept has been challenged by Ellison (18). In our population, further analysis which controlled for weight and height eliminated the significant effects of nutritional history on sexual malnutrition. This implies that the delays observed in the index girls are associated with the reduction in weight and height. The delay in onset of adolescence and menarche has been associated with periods of undernutrition during growth $(14,19)$. However, 
these studies do not distinguish between current undernutrition and malnutrition of early childhood. Our study demonstrates that a single early episode of malnutrition during the 1st yr of life is sufficient to cause a delay in menarche onset and the sexual maturation of girls.

The question thus arises concerning the nutritional status of the comparison and index girls. By North American standards, the pubescent comparison girls have a weight which approximates the 50th percentile and the index group lies at the 25 th percentile or lower. Since sexual maturation is delayed in the index girls, it is likely that at least part of this failure to gain weight and to accumulate additional body fat as rapidly as the comparison girls is due to delayed endocrine development. Thus, pubescent and postpubescent girls characteristically have increased body fat, as reflected in increased skinfold thickness as compared with less mature girls (20). Furthermore, medical examination and hematologic findings did not distinguish between index and comparison groups. It should be noted that the standards for height, weight, arm circumference, and skinfold thickness for the index group are at least as good as Cuban and Jamaican standards (21) for their normal populations, suggesting that the comparison Barbadian girls may be accumulating excessive amounts of body fat. In fact obesity is a known health problem in adult Barbadian women (Ramsey $\mathrm{F}$, personal communication), as it is in black US populations (20).

The possibility of a greater proportion of genetic late maturers in the index group cannot be entirely eliminated. However, early malnutrition, which is significantly correlated with these delays in physical growth and sexual maturation, seems a more obvious interpretation. Moreover, delays in sexual maturation are also seen following other childhood diseases such as hypothyroidism suggesting that endocrine development is sensitive to a variety of insults, including infantile malnutrition.

Finally, these data cannot be explained on the basis of differential treatment of boys and girls in Barbados. In an earlier paper of this series, we reported on the behavior at home of children in the study and found no differences in the parent-child interaction in relation to sex or nutritional history of the child (6). Socioeconomic status and home environmental conditions were also similar for boys and girls.

Acknowledgments. The authors thank the staff of the National Nutrition Centre, Richard Halperin, M.D., and Oneall Parris, M.D. for performing the medical examinations, and Robert Harrison, Ph.D. for statistical advice.

\section{REFERENCES}

1. Galler JR, Ramsey F, Solimano G, Lowell WE, Mason E 1983 The influence of early malnutrition on subsequent behavioral development. I) Degree of impairment in intellectual performance. J Am Acad Child Psychiatry 22:815

2. Galler JR, Ramsey F, Solimano G, Lowell WE 1983 The influence of early malnutrition on subsequent behavioral development. II) Classroom behavior. J Am Acad Child Psychiatry 22:16-22

3. Galler JR, Ramsey F, Solimano G, Lowell WE 1983 Sex differences in the growth of Barbadian school children with early malnutrition. Nutr Rep Int 27:503-517

4. Galler JR, Ramsey F, Solimano G 1984 The influence of early malnutrition on subsequent behavioral development. III) Learning disabilities as a sequel to malnutrition. Pediatr Res 18:309-313

5. Galler JR, Ramsey F, Solimano G, Kucharski LT, Harrison R 1984 The influence of early malnutrition on subsequent behavioral development. IV) Soft neurologic signs. Pediatr Res 18:826-832

6. Galler JR, Ramsey F, Solimano G 1985 The influence of early malnutrition on subsequent behavioral development. V) Child's behavior at home. J Am Acad Child Psychiatry 24:58-64

7. Galler, JR, Ramsey F, Solimano G, Jucharski LT The influence of early malnutrition on subsequent behavioral development. VI) The role of the microvenironment of the household. Nutr Behavior (in press)

8. Marshall WA, Tanner JM 1969 Variation in the pattern of pubertal change in girls. Arch Dis Child 44:291-303

9. Marshall WA, Tanner JM 1970 Variation in the pattern of pubertal change in boys. Arch Dis Child 45:13-23

10. Ramsey FC, 1980 Protein-Energy Malnutrition in Barbados. Josiah Macy, Jr. Foundation, New York

11. Zerfas AJ 1977 Anthropometric field measures: general, In: Jelliffe DB (ed) Nutrition and Growth. Plenum Press, New York, pp 339-387

12. Nie NH, Hull CH, Jenkins JG, Steinbrenner K, Bent DH 1979 SPSS: Statistical Package for the Social Sciences, 2nd ed. McGraw-Hill, Inc., New York

13. National Center for Health Statistics 1977 NCHS Growth Curves for Children, Birth-18 Years, United States. National Center for Health Statistics, Rockville, MD (Vital and Health Statistics. Series 11: Data from the National Health Survey, No, 165) DHEW Publication No PHS 78-1650

14. Dreizen S, Spirakis CN, Stone RE 1967 A comparison of skeletal growth and maturation in undernourished and well-nourished girls before and after menarch. J Pediatr 70:256-263

15. Briers PJ, Hoorweg J, Stanfield JP 1975 The long-term effects of protein energy malnutrition in early childhood on bone age, bone cortical thickness and height. Acta Paediatr Scand 64:853-858

16. Stoch MB, Smythe PM 197615 year developmental study on effects of severe undernutrition during infancy on subsequent physical growth and intellectual functioning. Arch Dis Child 51:327-336

17. Frisch R, Revelle R 1970 Height and weight at menarche and hypotheses of critical body weights and adolescent events. Science 169:397-399

18. Ellison PT 1981 Threshold hypotheses, development age, and menstrual func tion. Am J Phys Anthropol 54:337-340

19. Kulin HE, Bwibo N, Mutie D, Santher SJ 1982 The effect of chronic childhocd malnutrition on pubertal growth and development. Am J Clin Nutr 36.527536

20. Garn SM, Clark Dc 1976 Trends in fatness and the origins of obesity. Pediatric $57: 443-456$

21. Jordan, JR 1979 Desarrollo Humano en Cuba. Editorial Cientifica Tecnica, La Habana, Cuba 